\title{
The use of video in educational research and teacher training
}

$$
\text { in the digital classroom }
$$

\author{
Floriana Falcinelli ${ }^{\mathrm{a}}$, Cristina Gaggioli ${ }^{\text {b1 }}$ \\ ${ }^{a}$ Università degli Studi di Perugia, Italy, floriana.falcinelli@unipg.it, 0000-0003-2906-6356 \\ ${ }^{b}$ Università degli Studi di Perugia, Italy, cristina.gaggioli@gmail.com, 0000-0003-4161-390
}

\begin{abstract}
The introduction of new technologies, video in particular, in educational and pedagogical research has not only changed how research is conducted in the educational field but has also brought about significant changes in teacher training. The advent of digitalisation, along with the miniaturisation of both video cameras and storage media, has led to a dramatic increase in the use of video, particularly in terms of video production. This has led to the introduction of new teaching practices and new training initiatives derived from the analysis of these practices. The use of video, at an educational and didactic level on the one hand, and as an instrument for field observation on the other, offers a variety of benefits, along with some critical issues. One of the advantages is the capacity to allow for an analytical vision of complex actions, which may be reviewed at different times, by a variety of interlocutors. The aim of this study is to present a reflection based on research conducted in nine digital classes, focussing on the use of video as both an instrument for recording, collecting and analysing data, as well as a training tool in the didactic practice of teachers.
\end{abstract}

Keywords: in-service teacher training, information and communication technologies

\section{Introduction}

It has been established that in-class technologies can only be effective if teachers are capable of designing studentcentred teaching/learning paths. With the introduction of digital tools, the students can become the creator of their own journeys of discovery, with the guidance of a teacher who knows how to build a resource-rich, flexible environment that is open to research and constant monitoring.

This requires that teachers be trained not only in digital competences, but, above all, also in educational innovation processes that make creative and productive use of new technologies possible.

But such training, especially if carried out in service, cannot be characterised by a constant analysis of the educational practices carried out in class, in order to identify the positive elements to reinforce, and the critical issues to address, in order to optimise these processes.

The analysis of educational practices is a research procedure widespread in the European context, involving the study of the articulation of educational processes in a particular setting, in order to illuminate a series of actions that involve teachers and students, reflecting the complexity of the contexts in which the practice is carried out.

The concept of practice is not easy to define; however, practice may be regarded as a set of actions proposed to achieve an educational goal. In contrast with experience, which may be random, a practice is therefore a set of acts, routines and choices made in an intentional manner, in relation to a project.

Educational practice is viewed from a diachronic and holistic perspective as a process that moves towards more complex and evolved structures, and it involves multiple interacting systems, of which the most limited, while still notable, is the teacher/pupil ratio.

This process evolves through the continuous restructuring of conditions, interactions, inferences, expectations, cognitive strategies and the representation of relationships.

Research into the practice thus requires an 'epistemological break', in order to analyse not only concrete actions, but

\footnotetext{
${ }^{1}$ This article has been developed jointly by the two authors. Floriana Falcinelli wrote the following paragraphs: Introduction, Conclusion; Cristina Gaggioli wrote the following: Theoretical framework, Research design, Data analysis.
} 


\section{The use of video in educational research and teacher training in the digital classroom \\ Falcinelli, Gaggioli}

also the prerequisites, the meanings, the framework and the context of the educational content, as the fundamentals of any epistemological and theoretical elaboration. This necessitates the recognition and examination of the implicit and unspoken aspects of educational practice that inform actions (Laneve, 2005, p. 6).

The analysis of a practice places emphasis on the changes that involve strategies and the dynamics of the process, rather than the products obtained and the results achieved.

In this context, the study of the system of interrelationships that the various protagonists in the educational activity attempt to create becomes central, alongside the system of shared meanings and the methods of explanation for, interpretation of and intervention by concrete phenomena.

The main purpose of this research, characterised by the analysis of practices, is to investigate, not in a piecemeal fashion, but according to an integrated and complex logic of comprehension, the dynamics associated with educational practice, such as how do teachers, in the case of school practices, act in a certain context, and the meanings that people attribute to their actions, the expectations and anticipated outcomes that have been invested and the tacit knowledge that is implicated; all this is intended to interrogate the practices and problematise them, in order to improve and promote the quality of education, a factor that affects all the multiple and complex aspects of the practice, mainly the activity of the teacher in the relationship with the student.

This is why research characterised by the analysis of practices should also intend to promote and support the reflective practice of teachers, with regard to their actions, orienting them towards making choices and decisions with an increasing awareness that produces an improvement in the process itself.

In this context, the position of the researcher is different from that commonly adopted in academic contexts. The researcher cannot follow a predefined format and encode the epistemic system in advance; rather, the researcher has to structure it as a work in progress, according to an evolutionary logic based on the data that emerge from an exploratory analysis of the context, and he/she must therefore observe, record, analyse, reflect, discuss and reconsider the research experience.

For the research process to be defined as progressive, researchers and participants must contribute together: this makes it possible to grasp the specificity and uniqueness of the educational context in which they act, as well as the diversity of viewpoints, allowing for a comparison between the external perspective of the researcher and the interior view of the context. The results must be subjected to analysis by the participants, with the objective of finding a common interpretation: this requires that the participants, who are the operators of the practices, be considered active research subjects, whose manner of interpreting is fully justified by the epistemic process, with a role different from that of the academic researcher, for whom reaching an understanding involves a sustained involvement in the context while remaining external to it.

This outlines an epistemology of action that, as underlined by Schön (2006), encourages educators/teachers to develop the ability to reflect constantly before the action, during the action and on the action, to find appropriate solutions to problems and to constantly modify the action, making use of intervention strategies and, above all, their own viewpoint and choices.

On the other hand, what distinguishes a simple experience of intentional practice is the ability to make the motivations that guided the actions clear and explicit, in addition to the ability to implement them in relation to a constant process of conscious reflection.

It is important to reflect during the action, on the action, and on possible action. The capacity of reflective practice lies in the ability to recognise the occurrence of a determined event before it is banalised and treated as a preconceived interpretative category (Schön, 2006); a capacity for critical vigilance is necessary, along with authentic listening and the constant exercise of doubt (Mortari, 2003).

When the action has concluded, the reflection assumes a retrospective value, to better understand the meaning of certain decisions and their consistency with the paradigms of reference; it is appropriate to reflect on critical episodes and discontinuities.

This allows for a reflection on possible action, hypothesising future planning that also takes into account emotions, desires and expectations, in the knowledge of how best to reconcile rationality and the creative imagination (Mortari, 2009).

\section{Theoretical framework}

The first film documentation of cultural aspects dates back to the anthropological film, the history of which runs parallel to that of the narrative film, which began in 1895 with the Lumière brothers. At the same time, the Indian Harishchandra Sakharam Bhatavdekar filmed a wrestling match at the Hanging Gardens of Mumbai, Maharashtra: This is considered to be the first ethnographic film by a filmmaker based on their own culture. The footage shot by Alfred Haddon in 1898 is still considered to be the first example of the use of video in anthropological field research (Marazzi, 1998, pp. 117-118). Today, video documentation is seen as a form of communication, owing to the work of Deleuze $(1989)^{2}$, who developed the idea of a cinema that is not only a spectacle and the revelation of the imagination, but also a

\footnotetext{
${ }^{2}$ The reference is to the French philosopher Gilles Deleuze. Born in Paris on 18 January 1925, he is recognized as having been among the most innovative figures of twentieth century thought. He brought about a turning point in theoretical studies of cinema, by
} 


\section{The use of video in educational research and teacher training in the digital classroom \\ Falcinelli, Gaggioli}

form of expression of thought, which can translate and comment with observations, as is the case with an academic text or the novel (Corazza, 2012, p. 17). In the educational field, videos increasingly represent an important resource for learning. Alongside the traditional use of video in the context of information and entertainment, a growing interest in the use of this mode of communication can be observed in many areas of education, in the contexts of both the school and the workplace (Bonaiuti, 2013, p. 1).

In pedagogical literature, the most widespread use of video and Information and Communication Technology in teacher training involves either the representation of observed phenomena or the microanalytical examination of video cases, e.g., in microteaching. Video has also been used in education as a tool to stimulate reflexive processes. Its use in research is, however, more uncertain and nuanced. It is used to express emerging theories, as a testing ground for hypotheses, or for the narration of specific stories, as an instrument for theoretical production, or for the explication of the undeclared and the implicit (Galliani and De Rossi, 2014, p. 20). Audiovisual documentation must correspond to a methodological rigour that does not leave room for doubt regarding manipulation and secondary aims. This rigour requires that the reference criteria and techniques used are made clear and widely agreed. Collective reflection on the footage filmed can be useful for the actors in an educational setting during metacognition activities, in order to achieve a distance from themselves and make observations with a 'scientific' spirit, thus overcoming self-referentiality. Seeing oneself in a video recording means accepting a different point of view, that of the eye of the camera and the camera operator (Corazza, 2012, p. 19).

Studies conducted in Italy demonstrate that the culture of video research and video documentation is not yet widespread (Galliani and De Rossi, 2014, p. 130). However, in recent decades, the use of video cameras and video documentation for research purposes, in the international university context, has involved widespread use in the educational field, in particular with regard to the development of learning and teaching. This occurs not only in academic contexts, but also in schools, as the ease with which it is possible to create a digital video today has encouraged an increase in the use of video cameras, encouraging and stimulating constructive reflection on educational practices (Mazzucco and Maniero, 2014, p. 50).

In the context of pedagogy, video recording in the classroom is a technique that is suitable for two distinct occasions, which are closely interconnected in the case of research in the education field:

- As a recording tool in the research phase: as a recording instrument for the collection and analysis of data for teaching research. This makes it possible to initiate a deconstructive analysis of the processes in question, thus allowing for a far more thorough investigation, based on qualitative and quantitative models, which can be conducted by most researchers.

- As a training tool in educational practice: the stimulation of a process of reflexivity at different levels becomes an opportunity to encourage reflective thinking for the teachers involved, which touches upon the observation of classroom lessons, video footage, narration and group discussion, for the integrated construction of additional narratives (Tacconi and Gomez, 2013, p. 23).

With regard to the use of video recording in the field of research, considered an important tool for modern research, it can be seen as part of an experimental plan that makes use of observation as a methodology, which allows the researcher to describe and comprehend the phenomenon under analysis (Paparella and Santo, 1997, p. 47). Video recording is commonly used in observational research, as it is a technique that facilitates the observation of the behaviour of various subjects (Mantovani, 1998, p. 140). The use of video also represents an important opportunity to promote reflexive processes and critical thinking, with regard to actions performed on a daily basis by the protagonists operating in the analysed contexts. For this reason, interest in the use of this tool in training has increased in recent years.

From a methodological perspective, reviewing and using images to create individual and collective "contexts of speech' and reflection is of interest in training, as it helps reduce the gap between representations, which are often implicit, and practices, thus restoring a balance between theory and practice. The search for this balance responds to a current need, which is in line with both the increasing pressure for innovation in in-service training practices and the pedagogical literature that recognises the development of an identity capable of acting competently as central to the professionalism of the teacher, an identity that integrates theoretical and practical knowledge with subjective (emotional and cognitive) and sociocultural instances (Cescato, Bove and Braga, 2015, p. 62).

The use of video in educational settings and in the professional training of teachers has its roots in the practice of video recording of school lessons involved in microteaching. Microteaching is a teacher training technique developed by the School of Education at Stanford University and was first applied as a combined training and diagnostic tool in Stanford's teacher internship programme in the summer of 1963 (Allen, 1967, p. 2). This training practice requires that the trainee teacher prepares and simulates teaching microsequences for a small audience of students, which are observed by a group of trainee colleagues and the trainer supervisor. The microlesson is video recorded and subsequently subjected to an analytical study during which, through an analysis of the recording, the protagonist and observers identify peculiarities and limits among groups, which is useful in order to provide suggestions for improvement (Felisatti and Tonegato, 2013, p. 66).

demonstrating how the relationship between this form of expression and philosophy is based not on the supposed superiority of the latter, called upon to explicate concepts that happen to be present in cinematic images, but on an analogy of practices that involve both fields. From http://www.treccani.it/enciclopedia/gilles-deleuze (Enciclopedia-del-Cinema)/ 


\section{The use of video in educational research and teacher training in the digital classroom Falcinelli, Gaggioli}

One promising model is the video club, which brings teachers together to view and analyse video segments from one another's classrooms. The idea is that by watching and discussing video segments focussing on student thinking, teachers will learn practices to identify and analyse significant student thinking during instruction and be able to use what they learn to inform their instructional decisions. Video clubs are one way in which teachers can learn to hone these skills while also developing strategies for inquiring into student thinking as they teach (van Es, 2010, p. 58).

Another training method is the lesson study. The lesson study model originated in Japanese schools, even though it was in the United States that this methodology, which involves videotaping lessons, became a large-scale model for professional development as popularised through the Third International Mathematics and Science Study (TIMSS) videos.

On the basis of these studies, Santagata at the University of California has developed a model for teacher training (Santagata and Angelici, 2010), which describes an approach centred on the analysis of the teaching/learning process facilitated by the use of videotaped lessons, known as the Lesson Analysis Framework (Santagata, 2010, p. 11-12).

\section{Research design}

\subsection{Research questions}

The research essentially focusses on two questions: does the use of video as a documentation technique allow the researcher to analyse the data collected during field observation in greater detail? Can video be a valuable support to guide and stimulate reflection on the teaching practices and learning techniques implemented by teachers and students in a digital classroom?

\subsection{Participants}

The research project involved nine digital classes participating in the Millennium School Project ${ }^{3}$, located in two Italian regions: Umbria and Lazio. The unit of analysis included two second grade classes, two third grade classes and three fourth grade classes at the primary school level, as well as two second year classes at the lower secondary school level. The research involved a total of 161 students and 24 teachers.

\subsection{Procedure}

Santagata's model (Figure 1) for the use of video in vocational teacher training was used (Santagata, 2013) to answer the two research questions. With regard to the first point, namely, research, four dimensions have been defined for the creation of educational activities and the collection of data on the effect that the use of video has on the professional development of teachers.

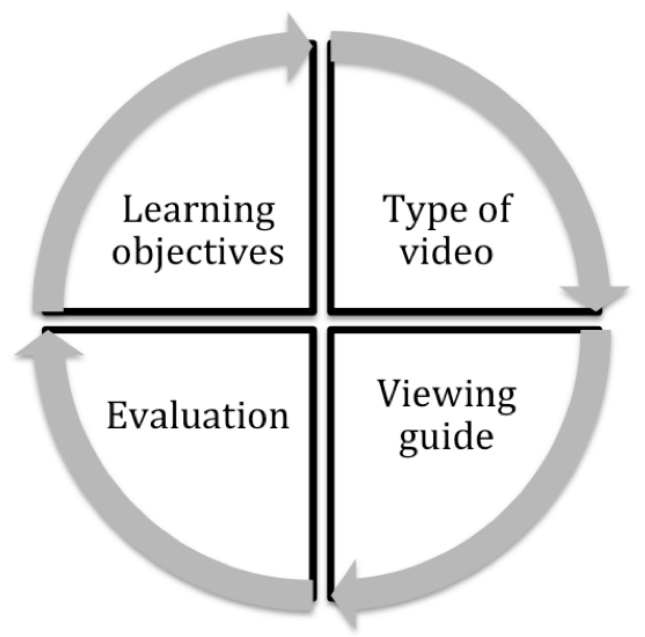

Fig. 1 Santagata's model for the use of video in vocational teacher training.

LEARNING OBJECTIVES: The objective of identification of learning objectives for teachers was to analyse how the learning setting changes in the presence of technology, which teaching practices are implemented by the teacher in

\footnotetext{
${ }^{3}$ Millennium School is an international project that aims to create links between schools, students and teachers from around the world through the creation of digital classes. (From http://millenniumedu.org/multi-stakeholder-initiative/).
} 
the digital classroom and how the roles of the teacher and the student change.

TYPE OF VIDEO: This includes the category of video to be used, in terms of focus, duration, editing, actors and type of teaching. The type of video used for viewing is a montage lasting about 15 minutes, which contains the initial 5 minutes of the lesson, in which the teacher begins the didactic activity, 5 central minutes, in which pupils are filmed during the activities, and the final 5 minutes of the lesson. All this is extrapolated from the complete recording of the lesson, which is observed for a period of 2 hours. In total, nine classes were filmed (one recording for each class involved), for a total of about 18 hours of footage. These recordings were subsequently transcribed by the researcher in narrative documentation format. This was later shared with teachers in discussion groups, in the presence of a second researcher. The video was presented to teachers within the discussion groups organised for this purpose. Beyond the noted edits, the video did not undergo any form of intervention, with the original soundtrack recording being left untouched.

VIEWING GUIDE: The aim of the training sessions was to go beyond first impressions, which can often be superficial, and help teachers to recognise behaviours and decisions that have an important effect on the learning outcomes of pupils. The discussion groups, as well as the data collection process that enables understanding the dynamics that are the subject of research, constitute an occasion that offers the teachers training opportunities. The teachers were encouraged to go beyond their first impressions and undertake sustained observation of behaviours and decisions, not simply focus and comment on the teacher's actions in the video. They were also led to reflect systematically on their work and the effects that it produces, or can produce, on student learning. To achieve this, the group discussions, which followed the viewing of the video recordings, were focussed on certain previously established aspects.

EVALUATION: The creation of the assessment categories made it possible to assign a score to the comments collected based on various dimensions. The group discussions were audio-recorded and faithfully transcribed, so that, after creating the categories, it was possible to qualitatively analyse their content with the use of the NVivo software.

With regard to the aspect most closely related to teacher training, reference was made to the previously cited Lesson Analysis Framework. This is based on the identification of four processes that guide the analysis of the lesson:

- The identification of the learning objectives: the teacher is called upon to define the principal learning goal of the proposed lesson.

- Analysis of student learning: the teacher reports on the progress made and difficulties encountered.

- Construction of hypotheses concerning the effects of learning and teaching strategies: the teacher is called upon to consider which strategies have facilitated student learning and which have not yielded the expected results.

- Use of the product to produce alternative teaching strategies: the teachers propose new strategies to implement, evaluating the impact that these may have on student learning.

\subsection{Research instruments}

An observation grid and a guide for the management of the discussion groups were prepared for the collection of data. These two instruments served to gather the information necessary to guide the analysis of the researchers, according to the research objectives. The focus of the analysis was, therefore, on the following themes:

- Instructions for the use of the technology by the pupils.

- Organisation of the work in the classroom.

- Person(s) to whom the management of the instruments in the classroom is entrusted.

- The timing of the use of the technology in the classroom.

- The existence of training courses that promote the basic computer skills necessary for the use of the device by the pupils.

- The perception of feelings of frustration on the part of pupils in the event of technology failure.

\section{Data analysis}

The information collected as part of the research project involves three types of documents: videos, the researcher narration, as guided by the observation grid, and the transcript of the comments that emerged in discussion groups. The $\mathrm{N}$-Vivo software was used in the organisation, analysis and codifying operations, which enabled the importation of different textual and audiovisual formats, which were then organised and classified according to the identified categories (Giannandrea, Fedeli and Fiorani, 2012, pp. 266-267). The resulting data (Falcinelli and Gaggioli, 2016) are summarised in Table 1. 


\section{The use of video in educational research and teacher training in the digital classroom \\ Falcinelli, Gaggioli}

Table 1. Table summarising the resulting data.

\begin{tabular}{|c|c|c|c|c|c|c|c|c|c|}
\hline & \multirow{2}{*}{$\begin{array}{l}\text { PASSIGNANO } \\
\text { Il grade } \\
\text { primary school }\end{array}$} & \multirow{2}{*}{$\begin{array}{l}\text { MARSCIANO } \\
\text { II grade } \\
\text { primary } \\
\text { school }\end{array}$} & \multicolumn{4}{|l|}{ FOLIGNO } & \multirow{2}{*}{$\begin{array}{l}\text { TERNI } \\
\begin{array}{l}\text { Fourth year } \\
\text { primary } \\
\text { school }\end{array}\end{array}$} & \multirow{2}{*}{$\begin{array}{l}\text { ROMA } \\
\text { Second year } \\
\text { secondary } \\
\text { school }\end{array}$} & \multirow{2}{*}{$\begin{array}{l}\text { FABRO } \\
\text { Second year } \\
\text { secondary } \\
\text { school }\end{array}$} \\
\hline & & & $\begin{array}{l}\text { Third } \\
\text { year } \\
\text { A }\end{array}$ & $\begin{array}{l}\text { Third } \\
\text { year } \\
\text { B }\end{array}$ & $\begin{array}{l}\text { Fourth } \\
\text { year } \\
\text { A }\end{array}$ & $\begin{array}{l}\text { Fourth } \\
\text { year } \\
\text { B }\end{array}$ & & & \\
\hline $\begin{array}{l}\text { Purpose of } \\
\text { using tools } \\
\text { (according to } \\
\text { the students) }\end{array}$ & Photos/videos & $\begin{array}{l}\text { Videos and } \\
\text { music }\end{array}$ & $\begin{array}{l}\text { Games a } \\
\text { photos }\end{array}$ & & \multicolumn{2}{|c|}{$\begin{array}{l}\text { Games and } \\
\text { photos }\end{array}$} & $\begin{array}{l}\text { Limited } \\
\text { uses of } \\
\text { photos }\end{array}$ & $\begin{array}{l}\text { Scholastic } \\
\text { uses and } \\
\text { music }\end{array}$ & $\begin{array}{l}\text { Scholastic } \\
\text { uses }\end{array}$ \\
\hline $\begin{array}{l}\text { Organisation } \\
\text { of didactic } \\
\text { work }\end{array}$ & $\begin{array}{l}\text { Individuals } \\
\text { work }\end{array}$ & $\begin{array}{l}\text { Individuals } \\
\text { work/peer } \\
\text { tutoring }\end{array}$ & \multicolumn{2}{|c|}{$\begin{array}{l}\text { Individuals with } \\
\text { tablets/collectives } \\
\text { with e-board }\end{array}$} & \multicolumn{2}{|c|}{$\begin{array}{l}\text { Individuals with } \\
\text { tablets/collectives } \\
\text { with e-board }\end{array}$} & $\begin{array}{l}\text { Individuals } \\
\text { and as } \\
\text { teams }\end{array}$ & $\begin{array}{l}\text { Cooperative } \\
\text { learning }\end{array}$ & $\begin{array}{l}\text { Cooperative } \\
\text { learning }\end{array}$ \\
\hline $\begin{array}{l}\text { Positive } \\
\text { results: pupils } \\
\text { with special } \\
\text { educational } \\
\text { needs }\end{array}$ & N.R. & N.R. & Yes & & Yes & & No & Yes & Yes \\
\hline $\begin{array}{l}\text { Who } \\
\text { manages the } \\
\text { technological } \\
\text { instruments in } \\
\text { the class? }\end{array}$ & Teacher & $\begin{array}{l}\text { One acting } \\
\text { student }\end{array}$ & Teacher & & Teacher & & $\begin{array}{l}\text { All } \\
\text { students }\end{array}$ & All students & All students \\
\hline $\begin{array}{l}\text { Use of the } \\
\text { technology in } \\
\text { the class }\end{array}$ & Sporadic & Sporadic & Sporadic & & Sporadic & & Quotidian & Quotidian & Quotidian \\
\hline $\begin{array}{l}\text { Frustration } \\
\text { while using } \\
\text { the } \\
\text { technological } \\
\text { instrument }\end{array}$ & Yes & Yes & Yes & & Yes & & No & No & No \\
\hline $\begin{array}{l}\text { Existence of } \\
\text { an } \\
\text { educational } \\
\text { course for the } \\
\text { use of the } \\
\text { computer } \\
\end{array}$ & Yes & Yes & Yes & & Yes & & Yes & Yes & Yes \\
\hline $\begin{array}{l}\text { What pupils } \\
\text { like }\end{array}$ & Everything & & Games & & & & Research & Cooperative & arning \\
\hline $\begin{array}{l}\text { What pupils } \\
\text { dislike }\end{array}$ & Nothing & & Write & & & & $\begin{array}{l}\text { Ache for } \\
\text { eyes }\end{array}$ & Technical pro & lems \\
\hline
\end{tabular}

After an initial observation by the researcher, from an analysis of the reflections shared in the groups, it emerged that the introduction of technology in the classroom occurs gradually and that it is differentiated according to the different types of schools. In the early classes of primary school, the use of technology remains sporadic, and the children tend to want to play extensively with the means put at their disposal. It can be noted that in the second grade of primary school, the use of the device by pupils is sporadic (at most twice a week). Children are therefore still very much intrigued by these instruments and tend to want to use them to play games or take photos. In these cases, it is the teacher who manages and delivers the instruments for the class and is responsible for putting them away at the end of the day. In this phase, the teacher tells the students how to turn the computer on and off, as well as how to save files. The classwork tends to have a more individual focus, with students working in pairs in some cases. The higher the grade, the more these devices are used daily, and the tendency to play with the instrument decreases. The researcher, after analysing the video of 17 February 2015 in a second grade class of primary school, reports that 'three students, at least, lose their work and so they have to begin their test again because of the lack of Internet connection. At the beginning all the students get irritated, which the researcher can understand from their voice inflexion, but then they begin their test again.'

In classes where these tools are used daily, the computer is seen by the students as a working tool for school use, and it is managed by the students themselves, who are responsible for putting the computers away in the lockers, where it is 
also possible to charge the devices. The researcher, during an observation made on 6 March 2015 in a fourth grade class of a primary school, reports 'at 11:24, the teacher draws the students' attention, by a triangle, to communicate to them that there is a problem in using the files because of a file damage. So a pupil helps the teacher in getting a little box containing some pen drives that will be used to transfer the files from the teacher's computer to the children's one.'

While the use of these tools is more advanced, there are still training sessions on information technology issues, which deal with increasingly advanced aspects over the years. During a discussion group in a second grade class of primary school conducted on 29 April 2015, some teachers report, 'at the beginning, we have taught the children, using the e-board, how to use a computer, specifically how to create and save a file; some children learn quickly, others need more time to learn. At home, some children usually use their tablet or computer to play, listen to the music, download images and music, but they never use their computer for didactic purpose.'

The daily use of the device and the growing acquisition of increasingly advanced computer skills by the pupils mean that the frustration caused by computer malfunction and, above all, the limited ability to use the tools by students, as registered in the second to the fourth grade classes of primary school, was not present later. In classes wherein the use of the device is systematic and of daily occurrence, the students do not manifest feelings of frustration if the instrument does not work as expected. The greater the degree of mastery that the students demonstrate in the use of the instruments, the more the teacher can allow the students to work with autonomy. Indeed, in the higher classes, work in small groups prevails.

\section{Conclusions}

This study has highlighted how the analysis of practices can become a training tool in the logic of the reflective practitioner, if it is taken as a specific procedure, which is methodical, partially orchestrated and ethically controlled, apart from being activated in a specific training context, oriented towards improved control of their personal and professional lives.

The analysis of practices used in the training of professionals is therefore a procedure designed for the development of the teacher's skills and professional identity through the development of a reflexive attitude.

This is a group process, conducted among peers, in which questions are asked, points of view expressed and comparisons and discussions encouraged; it requires a genuine questioning about the meaning of the action and is always attended by a trainer who, as an expert, facilitates distancing and reflexivity.

This is an orchestrated procedure, involving the implementation of knowledge and analytical tools, including the use of video, in order for the teachers to review their performances, together with others, and reflect on their practices (Altet, 2003, pp.142-143).

\section{References}

Allen, D. W. (1967). Micro-Teaching, a Description. Stranford University Press: ERIC.

Altet, M. (2003). La ricerca sulle pratiche di insegnamento in Francia. Brescia: La Scuola, pp.142-143.

Bonaiuti, G. (2013). Editoriale. Form@Re - Open Journal For Network Training, 12(79), 1-2. doi:10.13128/formare12595

Cescato, S., Bove, C., \& Braga, P. (2015). Video, formazione e consapevolezza. Intrecci metodologici.Form@Re Open Journal For Network Training, 15(2), 61-74. doi:10.13128/formare-17062

Corazza, L. (2012). Il video, un mediatore per 1'apprendimento.Form@ re-Open Journal per la formazione in rete, $12(79), 13-21$.

Falcinelli, F. \& Gaggioli, C. (2016, March), Digital classroom and educational innovation. Paper presented at the 10th International Technology, Education and Development Conference, Valencia, Spain.

Felisatti, E., \& Tonegato, P. (2013). Il laboratorio di Microteaching nel Tirocinio OnLine per la formazione iniziale degli insegnanti.Form@Re - Open Journal For Network Training, 12(79), 64-70. doi:10.13128/formare-12602

Galliani, L., \& De Rossi, M. (Ed) (2014). Videoricerca e documentazione narrativa nella ricerca pedagogica. Modelli e criteri. Lecce-Rovato: Pensa Multimedia Editore.

Giannandrea, L., Fedeli, L. \& Fiorani, H. (2012). Ricerca pedagogica e strumenti tecnologici: le tecnologie stanno cambiando il modo di fare ricerca. Il futuro della ricerca pedagogica e la sua valutazione, Quaderni della rivista Education Sciences \& Society, Roma, Armando Editore, 259-271.

Laneve, C. (2005). Analisi della pratica educativa. Metodologia e risultanze della ricerca. Brescia: La Scuola, p. 6.

Mantovani, S. (Ed) (1998). La ricerca sul campo in educazione. I metodi qualitativi. Milano: Edizioni Bruno Mondadori.

Mazzucco, C. \& Maniero S. (2014). La letteratura scientifica nel settore della videoricerca. Linee interpretative. In L. Galliani \& M. De Rossi, Videoricerca e documentazione narrativa nella ricerca pedagogica. Modelli e criteri. (pp. 50-51). Lecce-Rovato: Pensa Multimedia Editore. 
Marazzi, A. (1998). Lo sguardo antropologico. Processi educativi e multiculturalismo. Roma: Carocci editore.

Mortari, L. (2003). Apprendere dall'esperienza. Roma: Carocci.

Mortari, L. (2009). Ricercare e riflettere. La formazione del docente professionista. Carocci: Roma.

Paparella, N., \& Santo, A. (1997). Pedagogia sperimentale. Lecce: Pensa Multimedia Editore.

Santagata, R. (2010). L'analisi sistematica di lezioni videoregistrate. Un modello per la formazione degli insegnanti. Psicologia e scuola. Giunti, Nov-Dic. 2010, pp. 11-16.

Santagata, R. (2013). Un modello per l'utilizzo del video nella formazione professionale degli insegnanti.Form@Re Open Journal For Network Training, 12(79), 58-63. doi:10.13128/formare-12601

Santagata, R., \& Angelici, G. (2010). Studying the impact of the lesson analysis framework on preservice teachers' abilities to reflect on videos of classroom teaching. Journal of Teacher Education, 61(4), 339-349.

Schön, D.A., (2006). Il professionista riflessivo. Bari: Dedalo.

Tacconi, G., \& Gomez, G. (2013). Osservazione in classe e videoriprese come strumenti per lo sviluppo professionale dei docenti e la ricerca didattica. Note di metodo su un'esperienza in corso nella Provincia di Bolzano.Form@Re Open Journal For Network Training, 12(79), 22-33. doi:10.13128/formare-12598

van Es, E. A. (2010). Viewer Discussion Is Advised: Video Clubs Focus Teacher Discussion on Student Learning. Journal of staff development, 31(1), 54-58. 